\title{
Phase evolution and microstructural characterization of sintered ceramic bodies from contaminated marine sediments
}

M. Romero ${ }^{\mathrm{a}, *}$, A. Andrés ${ }^{\mathrm{b}}$, R. Alonso ${ }^{\mathrm{b}}$, J. Viguri $^{\mathrm{b}}$, J.Ma. Rincón $^{\mathrm{a}}$

a Group of Glassy and Ceramic Materials. Department of Building Construction Systems. Institute of Construction Sciences Eduardo Torroja-CSIC. C/ Serrano Galvache, 4. 28033 Madrid, Spain.

b Department of Chemical Engineering and Inorganic Chemistry. University of Cantabria. Avda. Los Castros s/n. 39005 Santander, Spain.

* Corresponding author. Tel./fax: 34913020440 / 34913020700

E-mail address: mromero@ietcc.csic.es

\begin{abstract}
The phase evolution during firing of ceramic bodies from three different contaminated marine sediments was investigated as a function of temperature. The mineralogical evolution examined by X-ray diffraction (XRD) revealed that quartz, which is a main crystalline phase in the original marine sediments, remains as a main phase in the sintered bodies. In addition, a glassy phase and new crystalline phases appear as result of different chemical reactions during firing. Scanning electron microscopy (SEM) showed a homogeneous microstructure composed by pores, crystals and a ceramic matrix. Energy X-ray dispersive spectroscopy (EDS) analyses permitted to distinguish the crystalline phases previously identified by XRD and also minor phases, which were not detected in the X-ray diffractograms.
\end{abstract}

Keywords: A. Sintering; B. Electron microscopy; B. X-ray methods; Marine sediments

\section{Introduction}

Marine sediments are deposited material consisting of insoluble material (rock and soil particles), organic matter and remains of marine organisms that accumulate on the seafloor. Marine sediments vary widely in composition and physical characteristics as a function of water depth, distance from land, variations in sediment source, and the physical, chemical, and biological characteristics of their environments.

Due to the exposure to industrials effluents, sediments may contain high levels of contaminants or pollution. Once the potential risks of contaminated sediments have been assessed, it would be necessary remediation actions including dredging ${ }^{1}$. Since dredged material may be contaminated, it will be necessary to carry out a characterization to decide the most suitable destination for the material ${ }^{2}$. The options in dredged material management, depending on the legal framework ${ }^{3-4}$, are re-collocation in the water system, beneficial use, treatment and confined disposal. 
Sediments from Santander and Suances Cantabrian estuaries (Northern Spain) have been previously characterised by different chemical and ecotoxicological parameters in order to study the pollution of these coastal areas. Sediments from both estuaries contain significant concentrations of heavy metals and organic pollutants derived from intensive industrial, agricultural and urban activities, making necessary treatment and confined disposal to manage them properly ${ }^{5-8}$.

The valorisation of wastes as secondary raw materials in the production of construction materials could allay the problems associated to both, the depletion of natural resources and the disposal of industrial wastes. Among construction materials, traditional claybased materials are heterogeneous products that can accommodate different inorganic wastes or sub-products without modification of its production process or the final product properties $^{9-11}$. Consequently, the incorporation of industrial wastes or subproducts in bricks and tiles is becoming a frequent practice in the ceramic factories. In this sense, it has been conducted several studies in last years concerning to the production of bricks with the incorporation of both organic ${ }^{12-14}$ and inorganic wastes ${ }^{15-}$ 22 .

These investigations, focused in the development of clay/waste mixtures in order to obtain marketable ceramics materials, have shown same benefits as, i) saving of resource, raw material and energy; ii) positive effects on the brick-making process; iii) improving final product quality; iv) reducing the cost of final product due to using waste additive in the process.

In a previous work, the suitability of contaminated marine sediments dredged from the Santarder Bay and Suances estuary (Spain) as alternative raw materials in the manufacture of traditional clay based ceramic materials has been evaluated ${ }^{23}$. That study proved that it is possible to obtain dense sintered compacts from those highly contaminated marine sediments. Water absorption and mechanical properties shown that the specimens firing at their respective optimum sintering temperature met the requirement values established by different European Standards for high density traditional bricks, covering ceramic tiles as well as for the more demanding criteria to high density clinker bricks and pavement ceramic tiles. Based on these preliminary analyses, the investigation conclude that studied marine sediments can be used as secondary raw materials for the production of ceramic bricks, floor and wall tiles by powder technology.

In the ceramic process, a series of different chemical reactions and physical transformations take place during firing. As results, the mechanically weak green body is transformed into a strong product. The technological properties of the fired material are strongly dependent of both mineralogy and microstructure and their knowledge of will lead to optimisation of firing process and properties of end-products. The purpose of this work is to study the mineralogical changes take place during the sintering process of contaminated marine sediments as well as to analyse the microstructure of selected bodies fired at their optimum sintering temperature. 
M. Romero, A. Andrés, R. Alonso, J. Viguri, J.Ma. Rincón, Phase evolution and microstructural characterization of sintered ceramic bodies from contaminated marine sediments, Journal of the European Ceramic Society, 29 (2009) 15-22; doi:10.1016/j.jeurceramsoc.2008.04.038

\section{Experimental procedure}

Raw materials used in the present investigation were three marine sediments from the Santander Bay (Spain) denominated Astilleros and Raos, and from the Suances Estuary (Spain) denominated Cuchía. Table I shows the chemical analysis and mineralogical composition determined by X-ray fluorescence and X-ray diffraction respectively.

The as-received sediments were oven-dried at $105^{\circ} \mathrm{C}$ for $24 \mathrm{~h}$ and then crushed, grounded and finally powdered to $<160 \mu \mathrm{m}$ prior to their characterization and further use. The powders were compacted at $40 \mathrm{MPa}$ to form disc-shaped specimens $(2.0 \mathrm{~cm}$ in diameter and $0.5 \mathrm{~cm}$ in height), which were sintered in an electrically heated furnace at temperatures between $900^{\circ}$ and $1200^{\circ} \mathrm{C}$ by using a ramp rate of $15^{\circ} \mathrm{C} / \mathrm{min}$. The samples were hold at the maximum temperature for 1 hour and then cooled inside the furnace at a rate of $50^{\circ} \mathrm{C} / \mathrm{min}$ down to $500^{\circ} \mathrm{C}$.

Table I. Chemical (wt.\%) and mineralogical composition of the sediments, as determined by XRF and XRD.

\begin{tabular}{|c|c|c|c|}
\hline & Astilleros & Cuchia & Raos \\
\hline$\overline{\mathrm{SiO}_{2}}$ & $\begin{array}{l}47.13 \\
\end{array}$ & $\begin{array}{l}53.54 \\
\end{array}$ & $\overline{57.26}$ \\
\hline $\mathbf{A l}_{2} \mathbf{O}_{3}$ & 11.73 & 8.43 & 7.69 \\
\hline $\mathrm{Fe}_{2} \mathbf{O}_{3}$ & 21.55 & 4.50 & 4.13 \\
\hline MnO & 0.31 & 0.03 & 0.05 \\
\hline MgO & 1.46 & 2.36 & 3.60 \\
\hline $\mathrm{CaO}$ & 1.41 & 7.48 & 6.81 \\
\hline $\mathrm{Na}_{2} \mathrm{O}$ & 1.08 & 1.51 & 1.23 \\
\hline $\mathbf{K}_{2} \mathbf{O}$ & 1.62 & 1.85 & 1.83 \\
\hline $\mathrm{TiO}_{2}$ & 0.63 & 0.55 & 0.57 \\
\hline $\mathbf{P}_{2} \mathbf{O}_{5}$ & 0.23 & 0.17 & 0.17 \\
\hline LOI & 12.01 & 19.35 & 16.69 \\
\hline $\begin{array}{l}\text { Mineralogical } \\
\text { composition }\end{array}$ & $\begin{array}{l}\text { quartz } \\
\text { goethite }(\mathrm{FeO}(\mathrm{OH}))\end{array}$ & $\begin{array}{l}\text { quartz } \\
\text { calcite }\left(\mathrm{CaCO}_{3}\right) \\
\text { anhydrite }\left(\mathrm{CaSO}_{4}\right) \\
\text { dolomite }\left(\mathrm{CaMg}\left(\mathrm{CO}_{3}\right)_{2}\right) \\
\end{array}$ & $\begin{array}{l}\text { quartz } \\
\text { calcite }\left(\mathrm{CaCO}_{3}\right) \\
\text { anhydrite }\left(\mathrm{CaSO}_{4}\right) \\
\text { dolomite }\left(\mathrm{CaMg}\left(\mathrm{CO}_{3}\right)_{2}\right) \mathrm{Mg}_{2} \mathrm{SiO}_{4}\end{array}$ \\
\hline
\end{tabular}

The major crystalline phases of fired specimens were identified by X-ray diffractometry. Samples were crushed to fine powder in an agate mortar, passed through a 300 mesh sieve and then were scanned with $\mathrm{CuK}_{\alpha}$ radiation from $15^{\circ} \leq 2 \theta \leq 75^{\circ}$ at a scanning speed of $0.5^{\circ} / \mathrm{min}$, using a Philips X`PERT MPD diffractometer operating at $30 \mathrm{~mA}$ and $50 \mathrm{kV}$.

The microstructure of selected samples were examined by scanning electron microscopy (SEM) using a Jeol JSM 540 equipment operating at $20 \mathrm{kV}$. SEM specimens were polished using 6, 3 and $1 \mu \mathrm{m}$ diamond pastes after grinding with silicon carbide paper and water. The polished surfaces were Au-Pd coated. Energy dispersive X-ray spectroscopy (EDS) using a Link eXL detector was used to the semi-quantitative analysis. 
M. Romero, A. Andrés, R. Alonso, J. Viguri, J.Ma. Rincón, Phase evolution and microstructural characterization of sintered ceramic bodies from contaminated marine sediments, Journal of the European Ceramic Society, 29 (2009) 15-22; doi:10.1016/j.jeurceramsoc.2008.04.038

\section{Results and discussion}

\section{Mineralogical evolution during sintering}

Figure 1 shows the XRD plots of Astilleros sediment heat treated in the range $1000^{\circ}$ $1150^{\circ} \mathrm{C}$. Quartz $\left(\mathrm{SiO}_{2}\right)$ and hematite $\left(\mathrm{Fe}_{2} \mathrm{O}_{3}\right)$ are the main crystalline phases in all sintered samples. Hematite is a new phase formed in the course of sintering process as result of goethite dehydration and oxidation reactions, whereas quartz is a remaining phase from the original sediment. A small band in the $2 \theta=27.0-28.3^{\circ}$ interval must be due to minor crystalline phases that can not be identified by merely XRD analyses. Figure 2 depicts the intensity of the (100) quartz reflection and the (104) hematite reflection, which appear at $2 \theta=26.6^{\circ}(d=3.34 \AA)$ and $2 \theta=33.3^{\circ}(d=2.69 \AA)$ respectively. Both reflections, which give rise to the maximum intensity peak in the quartz and hematite pattern, are marked with the symbol $\downarrow$ in Figure 1 .

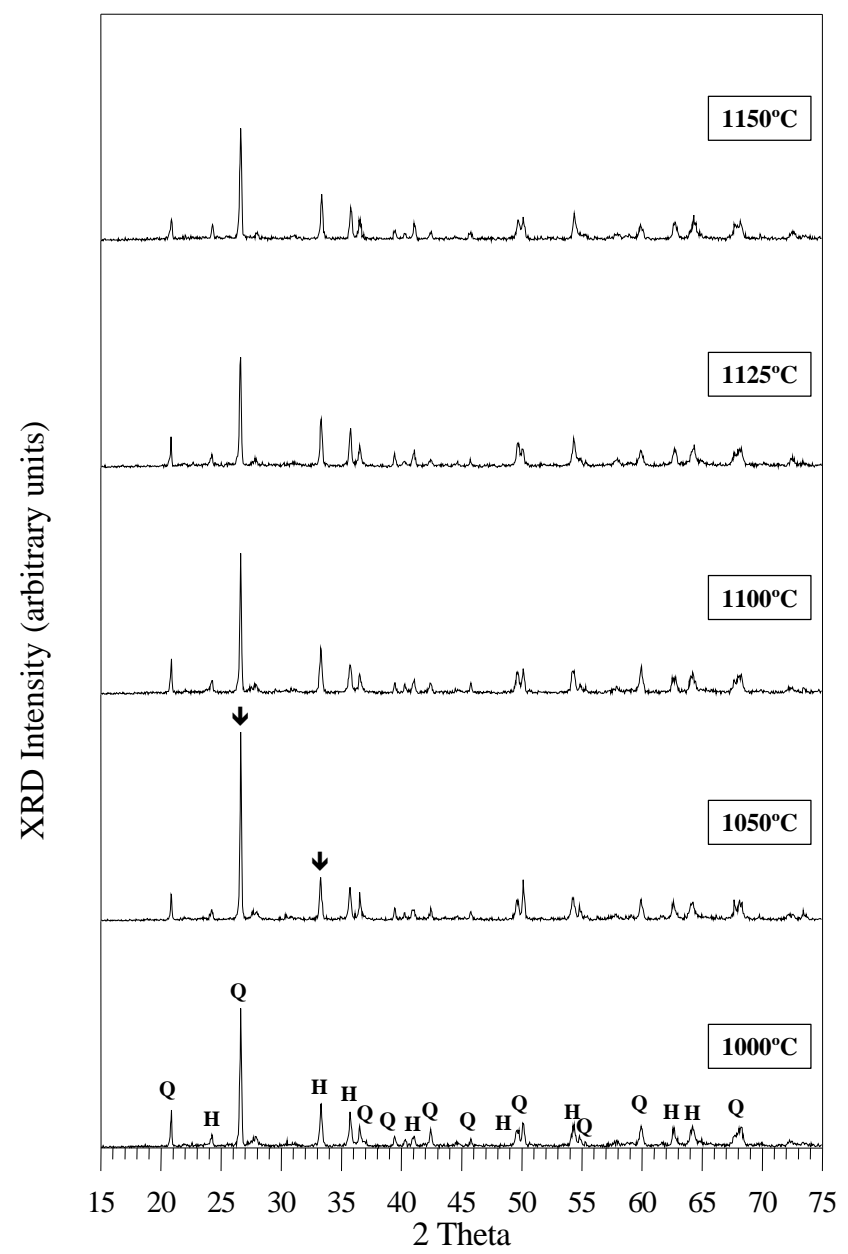

Figure 1. XRD plots of Astilleros sediment heat treated in the range $1000^{\circ}-1150^{\circ} \mathrm{C}(\mathbf{Q}$ quartz; $\mathbf{H}$ hematite).

Figure 2 also plots the change in the amorphous phase by considering the background intensity at the position of the (100) quartz reflection. Although quartz undergoes a slight increase at the beginning of sintering process, it tends to decrease with heating 
temperature. Glassy phase shows an inverse behaviour, indicating that both effects are connected. The increasing of sintering temperature gives rise to a partial dissolution of quartz grains and therefore, the amount of glassy phase increases. Finally, the proportion of hematite remains constant on the whole sintering temperature range.

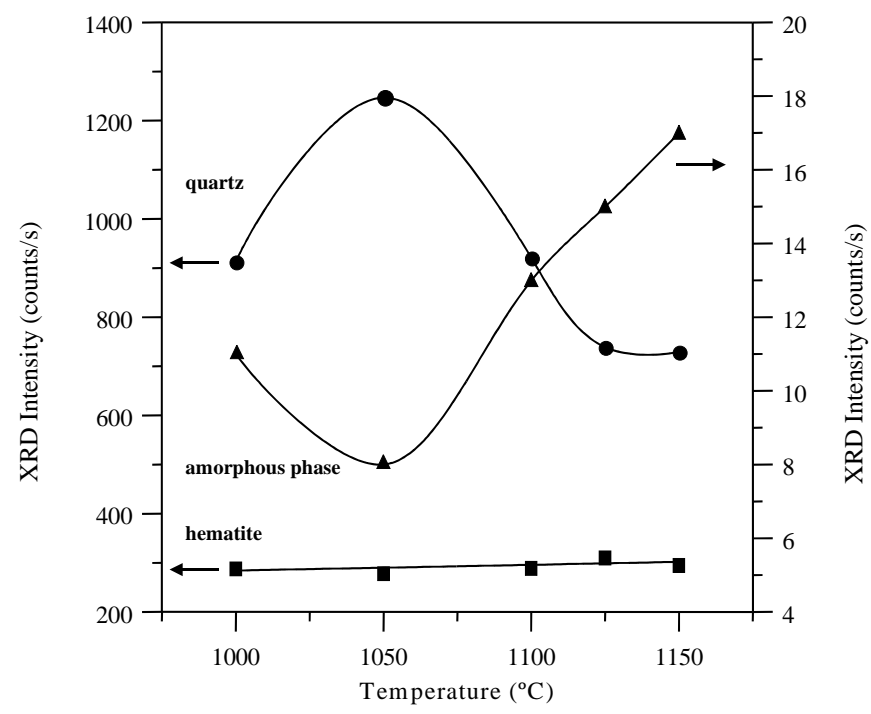

Figure 2. Intensity of the (100) quartz reflection, (104) hematite reflection and amorphous phase as function of firing temperature in sintered Astilleros sediments.

Figure 3 shows the mineralogical evolution of Cuchia sediment after sintering between $1100^{\circ}-1125^{\circ} \mathrm{C}$. As in Astilleros specimens, quartz and hematite are identified in XRD patterns, however the intensity of diffraction peaks points out that the relative percentage of both phases are different, being the quartz content greater in Cuchia sintered samples whereas hematite reflections are more clearly showed in Astilleros samples. Besides the above mentioned crystalline phases, clynopyroxene and spinel phases, such as augite $\left(\mathrm{Ca}(\mathrm{Mg}, \mathrm{Fe}) \mathrm{Si}_{2} \mathrm{O}_{6}\right)$, and magnesioferrite $\left(\mathrm{MgO} \cdot \mathrm{Fe}_{2} \mathrm{O}_{3}\right)$ are also identified in Figure 3.

Figure 4 depicts the evolution in quartz and augite reflections (marked on the $1115^{\circ} \mathrm{C}$ diffractogram in Figure 3) with increasing firing temperature. The (221) augite reflection, which appear at $2 \theta=29.8^{\circ}(d=2.99 \AA)$, was selected for drawing. The variation in the amorphous phase is also showed in Fig. 4. The intensity of augite crystals, formed in the first stages of sintering process, decreases in the $1100^{\circ}-1115^{\circ} \mathrm{C}$ interval due to decomposition and subsequent formation of a liquid phase. Quartz plot shows a similar behaviour than in Astilleros samples, with decreasing intensity above $1115^{\circ} \mathrm{C}$. Thereby, both effects augite decomposition and quartz dissolution result in a glassy phase increasing in the $1115^{\circ}-1125^{\circ} \mathrm{C}$ interval. 
M. Romero, A. Andrés, R. Alonso, J. Viguri, J.Ma. Rincón, Phase evolution and microstructural characterization of sintered ceramic bodies from contaminated marine sediments, Journal of the European Ceramic Society, 29 (2009) 15-22; doi:10.1016/j.jeurceramsoc.2008.04.038

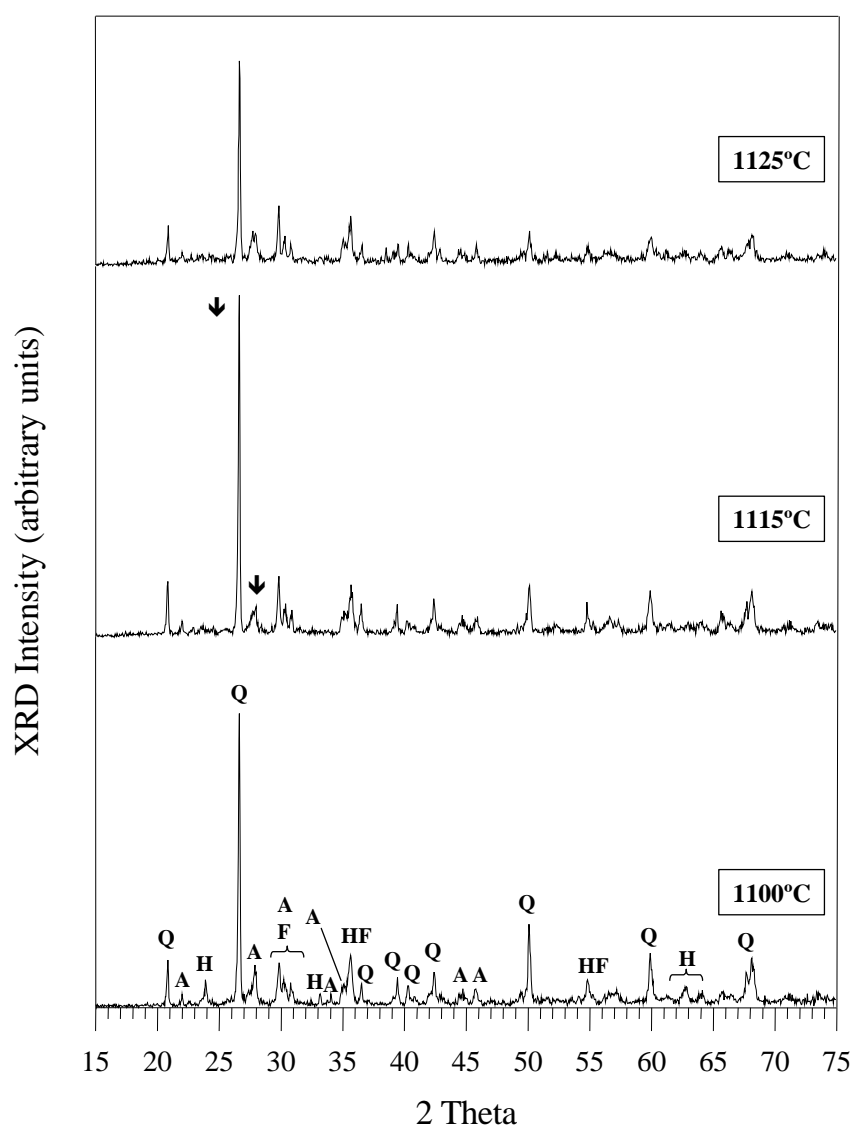

Figure 3. XRD plots of Cuchia sediment heat treated in the range $1100^{\circ}-1125^{\circ} \mathrm{C}(\mathbf{Q}$ quartz; $\mathbf{H}$ hematite; $\mathbf{A}$ augite; $\mathbf{F}$ magnesioferrite).

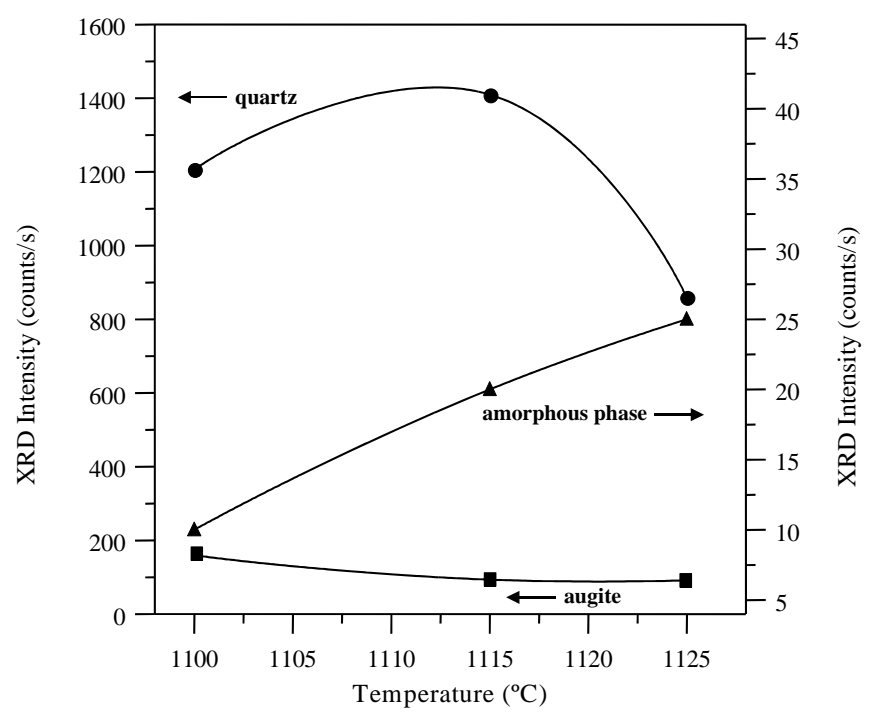

Figure 4. Intensity of the (100) quartz reflection, (221) augite reflection and amorphous phase as function of firing temperature in sintered Cuchia sediments. 
M. Romero, A. Andrés, R. Alonso, J. Viguri, J.Ma. Rincón, Phase evolution and microstructural characterization of sintered ceramic bodies from contaminated marine sediments, Journal of the European Ceramic Society, 29 (2009) 15-22; doi:10.1016/j.jeurceramsoc.2008.04.038

Unlike Astilleros and Cuchia sintered samples, hematite is absent in the XRD patterns collected on Raos samples sintered in the $1100^{\circ}-1150^{\circ} \mathrm{C}$ range (Figure 5). Quartz is again the main crystalline phase, together with magnesium iron aluminium silicate ((Mg,Fe,Al)(Si,Al) $\left.\mathrm{O}_{3}\right)$, augite $\left(\mathrm{Ca}(\mathrm{Mg}, \mathrm{Fe}) \mathrm{Si}_{2} \mathrm{O}_{6}\right)$ and a clynopyroxene, likely ferrosilite $\left((\mathrm{Mg}, \mathrm{Fe}) \mathrm{Si}_{2} \mathrm{O}_{6}\right)$. XRD reflections of the former crystalline phases are nearby and consequently the assignation of peaks in Fig. 5 is complex. Thus, Figure 6 plots the range $2 \theta=27-37^{\circ}$ of the X-ray pattern collected on Raos sediment sintered at $1115^{\circ} \mathrm{C}$, which has also allowed to recognize an new crystalline phase, in which $\mathrm{Al}^{3+}$ cations have been incorporated into the crystalline network of augite crystals, giving rise to an aluminian augite $\left(\mathrm{Ca}(\mathrm{Mg}, \mathrm{Fe}, \mathrm{Al})(\mathrm{Si}, \mathrm{Al})_{2} \mathrm{O}_{6}\right)$. Figure 7 shows the evolution in quartz, augite and ferrosilite reflections (marked on the $1115^{\circ} \mathrm{C}$ pattern in Fig. 6) in Raos samples. The (221) ferrosilite reflection, which appear at $2 \theta=27.9^{\circ}(\mathrm{d}=3.21 \AA$ ), was selected for drawing. In this case, the intensity of the amorphous and different crystalline phases remained approximately constant with increasing sintering temperature.

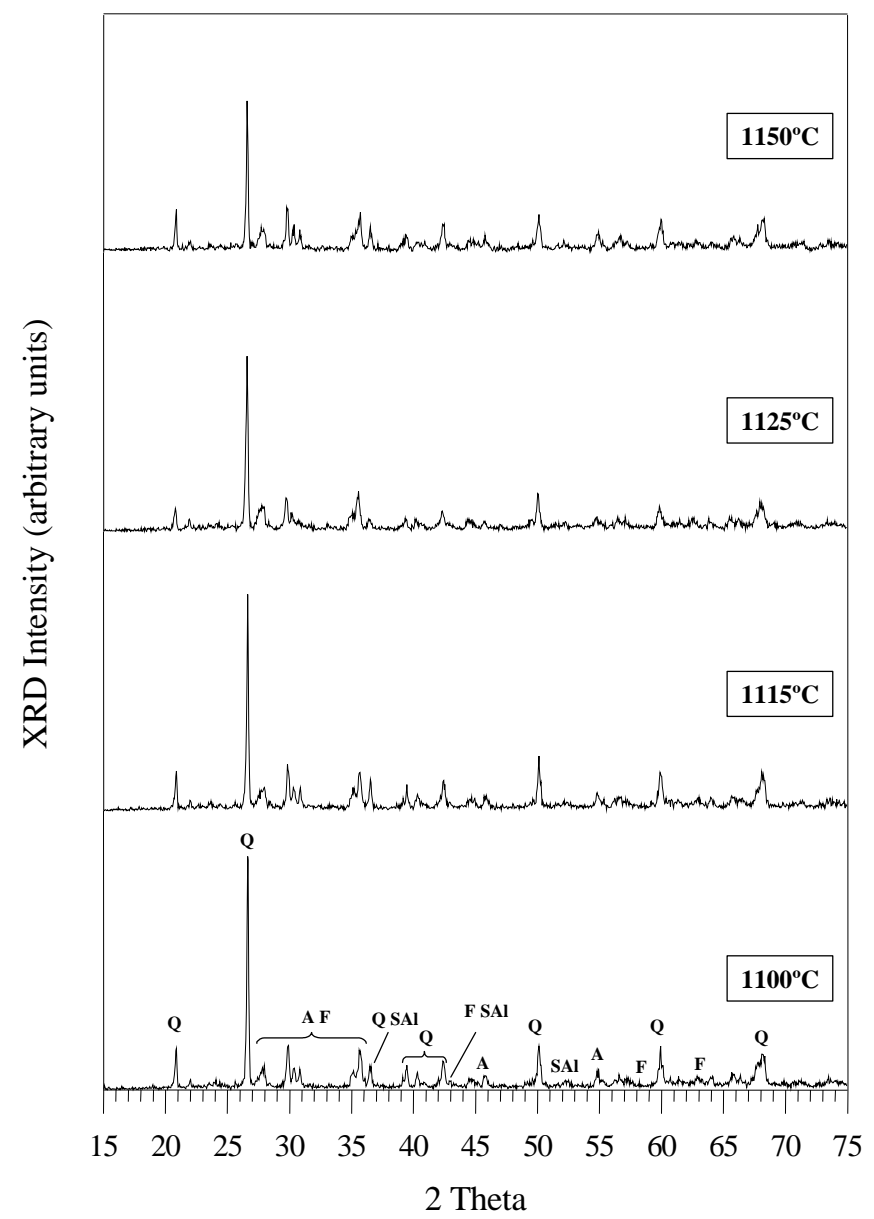

Figure 5. XRD plots of Raos sediment heat treated in the range $1100^{\circ}-1150^{\circ} \mathrm{C}(\mathbf{Q}$ quartz; A augite; F ferrosilite; SAl magnesium iron aluminium silicate). 
M. Romero, A. Andrés, R. Alonso, J. Viguri, J.Ma. Rincón, Phase evolution and microstructural characterization of sintered ceramic bodies from contaminated marine sediments, Journal of the European Ceramic Society, 29 (2009) 15-22; doi:10.1016/j.jeurceramsoc.2008.04.038

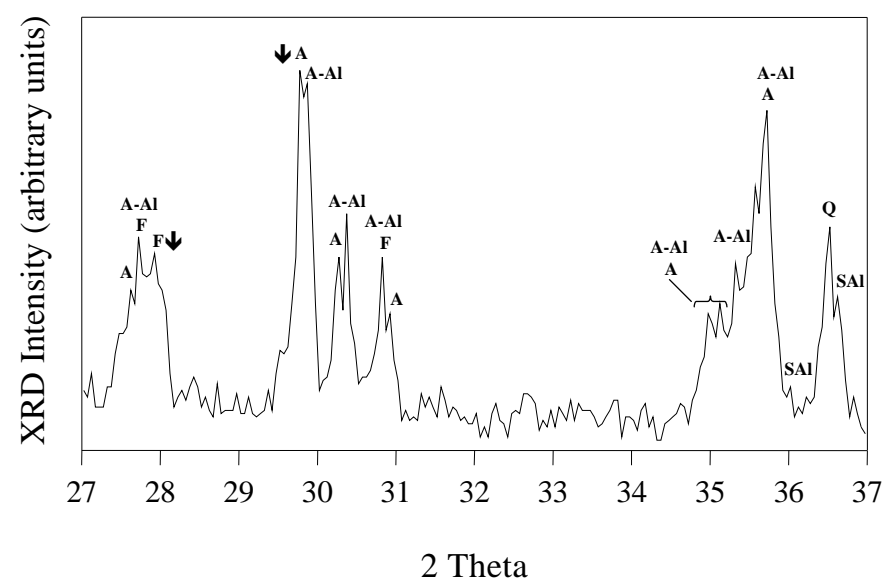

Figure 6. Plot of the range $2 \theta=27-37^{\circ}$ of the X-ray pattern collected on Raos sediment sintered at $1115^{\circ} \mathrm{C}$ (A augite; $\mathbf{F}$ ferrosilite; A-Al aluminian augite; $\mathbf{Q}$ quartz; SAl magnesium iron aluminium silicate).

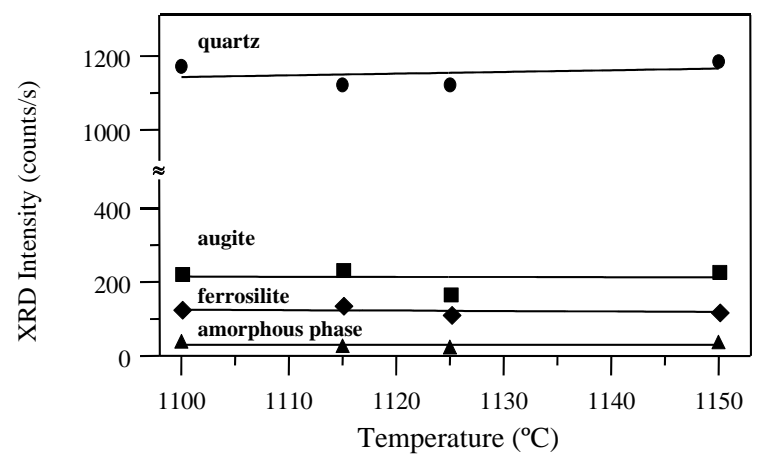

Figure 7. Intensity of the (100) quartz reflection, (221) augite reflection, (221) ferrosilite reflection and amorphous phase as function of firing temperature in sintered Raos sediments.

\section{Microstructural characterization}

Figure 8 shows show SEM observations on polished surfaces of sediments compacts fired for 1 hour at their optimum sintering temperature $\left(1125^{\circ} \mathrm{C}\right.$ for Astilleros and Cuchia and $1150^{\circ} \mathrm{C}$ for Raos sediment), which have been determined in a previous work $^{23}$. The three fired sediments show a homogeneous microstructure composed by isolated rounded pores, irregular shape and size crystals and a ceramic matrix surrounding the former phases. The main difference is the amount and size of close pores, which are greater in Cuchia and Raos likely due to the higher content in carbonates and sulphates in the original sediments, which lead to a great gases release.

Figure 9 presents EDS analyses collected on different crystals in Astilleros sediment sintered at $1125^{\circ} \mathrm{C} / 1$ hour. Large irregular crystals composed mainly by $\mathrm{SiO}_{2}$ (labelled "Q") are quartz, which has been identified by XRD as main crystalline phase. Lighter contrast crystals ("R") are mainly composed by $\mathrm{TiO}_{2}$ although EDS also detects an important content of $\mathrm{Fe}_{2} \mathrm{O}_{3}$, suggesting that they are ilmenite crystals, $\mathrm{FeO} \cdot \mathrm{TiO}_{2}$. However, the chemical composition of ilmenite $\left(52.65 \% \mathrm{TiO}_{2}, 47.35 \% \mathrm{FeO}\right)$ is far 
M. Romero, A. Andrés, R. Alonso, J. Viguri, J.Ma. Rincón, Phase evolution and microstructural characterization of sintered ceramic bodies from contaminated marine sediments, Journal of the European Ceramic Society, 29 (2009) 15-22; doi:10.1016/j.jeurceramsoc.2008.04.038

away to the EDS analysis showed in Fig. 9), suggesting that light grains must be rutile crystals, which have incorporated $\mathrm{Fe}^{3+}$ ions into their crystalline network. Indeed, it is knew an ilmenite-hematite solid solution developed by the substitution of one $\mathrm{Fe}^{2+} \mathrm{Ti}^{4+}$ group by two $\mathrm{Fe}^{3+}$ ions ${ }^{24,25}$. The upper micrography in Fig. 9 is an observation of the ceramic matrix at higher magnification. The matrix is comprised by potassium feldspar crystals ( $5 \mu \mathrm{m}$ average size), which show an EDS analysis ("S") close to the theoretical chemical composition of sanidine, $(\mathrm{K}, \mathrm{Na})(\mathrm{Si}, \mathrm{Al})_{4} \mathrm{O}_{8}\left(12.88 \% \mathrm{~K}_{2} \mathrm{O}, 2.82 \% \mathrm{Na}_{2} \mathrm{O}\right.$, $18.59 \% \mathrm{Al}_{2} \mathrm{O}_{3}, 65.71 \% \mathrm{SiO}_{2}$ ) and by white contrast hematite crystals, $\mathrm{Fe}_{2} \mathrm{O}_{3}$ (" $\mathrm{H}$ "), which is another phase clearly identified by XRD. The average size of hematite crystals $(0.66 \mu \mathrm{m})$ is under the analytical resolution limit of the microscope $(1 \mu \mathrm{m})$ and consequently, the EDS analysis is also detecting oxides from the glassy phase, which is surrounding the different crystalline phases.

a
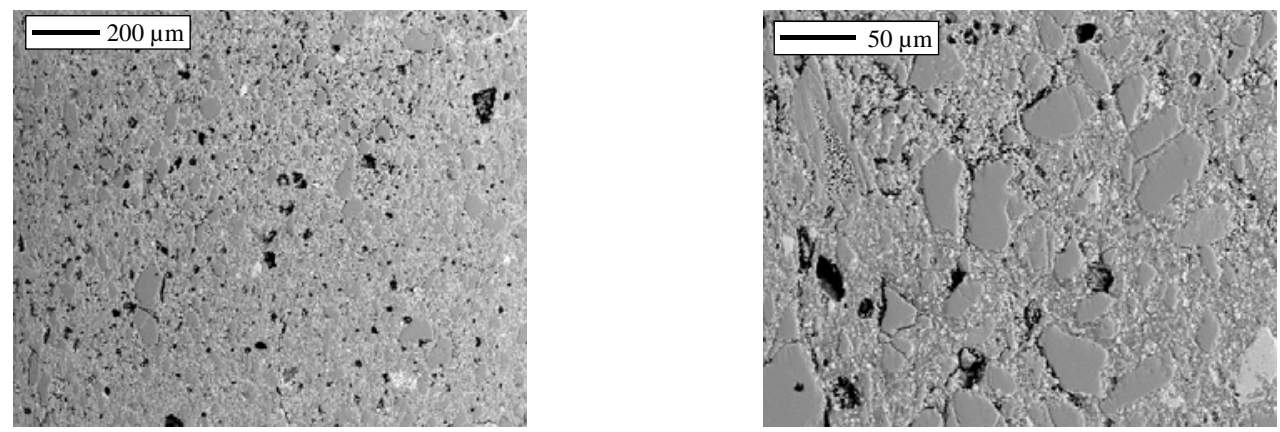

b
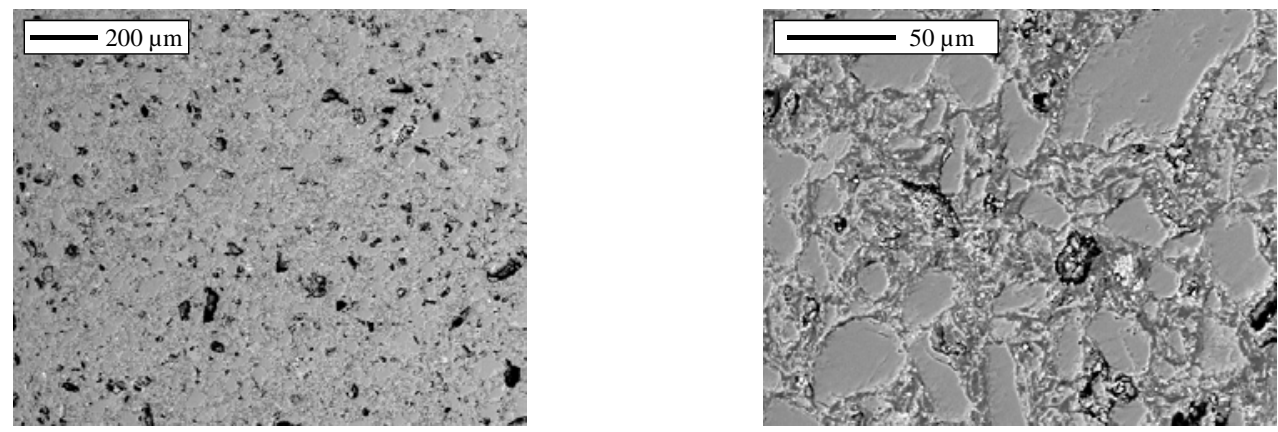

C
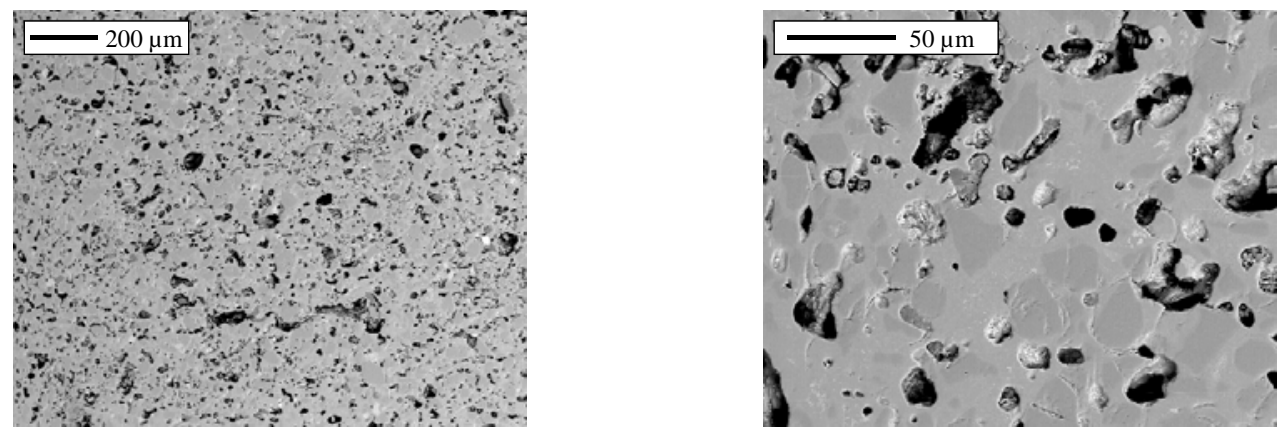

Figure 8. SEM observations on polished surfaces of marine sediments fired for 1 hour at their optimum sintering temperature (a Astilleros $1125^{\circ} \mathrm{C}$; b Cuchia $1125^{\circ} \mathrm{C}$; c Raos $\left.1150^{\circ} \mathrm{C}\right)$. 
M. Romero, A. Andrés, R. Alonso, J. Viguri, J.Ma. Rincón, Phase evolution and microstructural characterization of sintered ceramic bodies from contaminated marine sediments, Journal of the European Ceramic Society, 29 (2009) 15-22; doi:10.1016/j.jeurceramsoc.2008.04.038

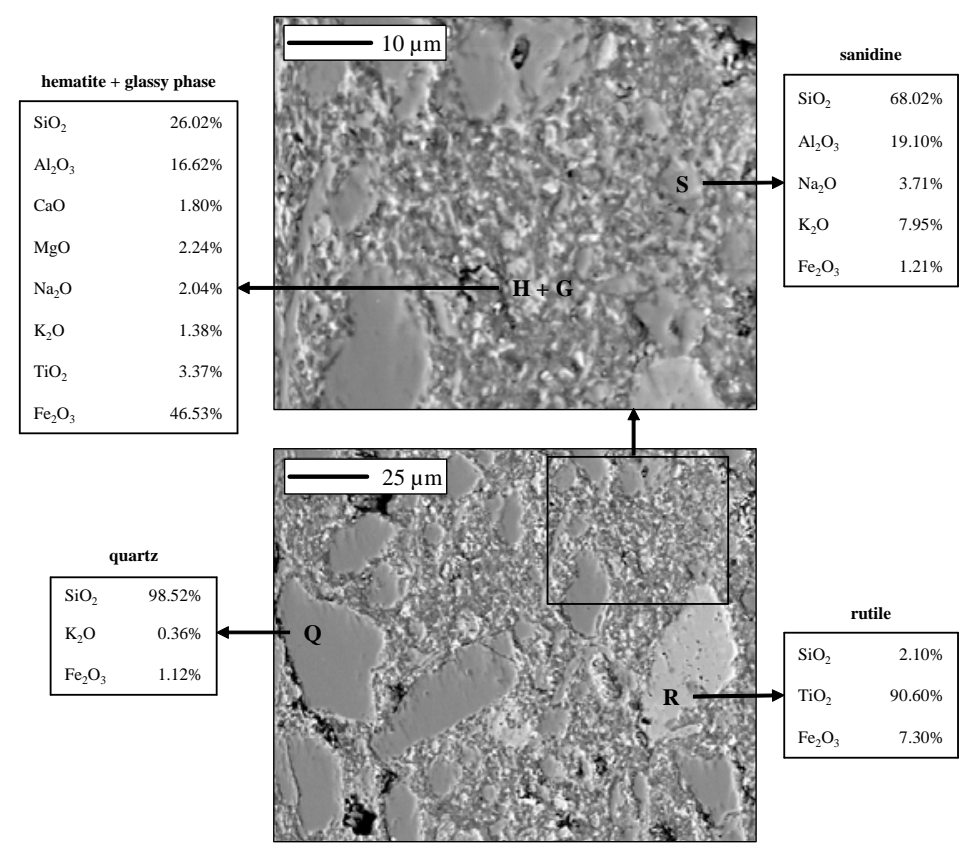

Figure 9. EDS analyses collected on different crystals in Astilleros sediment sintered at $1125^{\circ} \mathrm{C} / 1$ hour.

Figure 10 shows EDS analyses collected on different crystals in Cuchia sediment sintered at $1125^{\circ} \mathrm{C} / 1$ hour. Large irregular quartz crystals are clearly identified ("Q”). Similar to Astilleros sample, the average size of hematite crystals is lower than $1 \mu \mathrm{m}$ and EDS analyses collect elements from the surrounding glassy phase ("H"). However, crystals up to $2 \mu \mathrm{m}$ wide have been found in restricted areas. In the most case, iron peaks are mainly detected in the EDS spectra, which allow us to identify these longer crystals as hematite. Magnesioferrite crystals have the same morphoplogy and white contrast than hematite crystals. However, magnesioferrite crystals ("M") could be distinguished because the magnesium peaks are higher and the iron peaks lower in the EDS spectra from magnesioferrite, compared with those from hematite. Regarding augite crystals (“A”), they are forming a network homogeneously spread on the whole sintered sample. Finally, isolated rutile crystals ("R") are also detected in Cuchia sintered sample, being the incorporation of $\mathrm{Fe}^{3+}$ ions into the crystalline rutile network higher than in Astilleros sample.

Figure 11 presents EDS analyses collected on different crystals in Raos sediment sintered at $1150^{\circ} \mathrm{C} / 1$ hour. Darker regions ("Q") are quartz crystals. The presence of $\mathrm{R}^{+}$ and $\mathrm{R}^{2+}$ ions in the EDS spectrum of quartz grains suggest than the different chemical reactions to give a liquid phase have already started. A feldspar glassy phase ("G") is always surrounding to both quartz grains and augite crystallization regions ("A"). Ferrosilite phase appears as agglomerates of light contrast elongated crystals, which are distributed on the whole sample ("F"). SEM observations have also shown several dispersed crystalline agglomerates with higher titanium peaks and lower iron peaks ("MT”) compared with ferrosilite phase. These former agglomerates could be $\mathrm{MgTiO}_{3}$, which are not detected by XRD diffractograms due to their low contribution to the 
M. Romero, A. Andrés, R. Alonso, J. Viguri, J.Ma. Rincón, Phase evolution and microstructural characterization of sintered ceramic bodies from contaminated marine sediments, Journal of the European Ceramic Society, 29 (2009) 15-22; doi:10.1016/j.jeurceramsoc.2008.04.038

whole mineralogical phase distribution. Due to the small size of $\mathrm{MgTiO}_{3}$ and ferrosilite crystals, their EDS spectrums are also detected elements from the adjoining glassy phase.

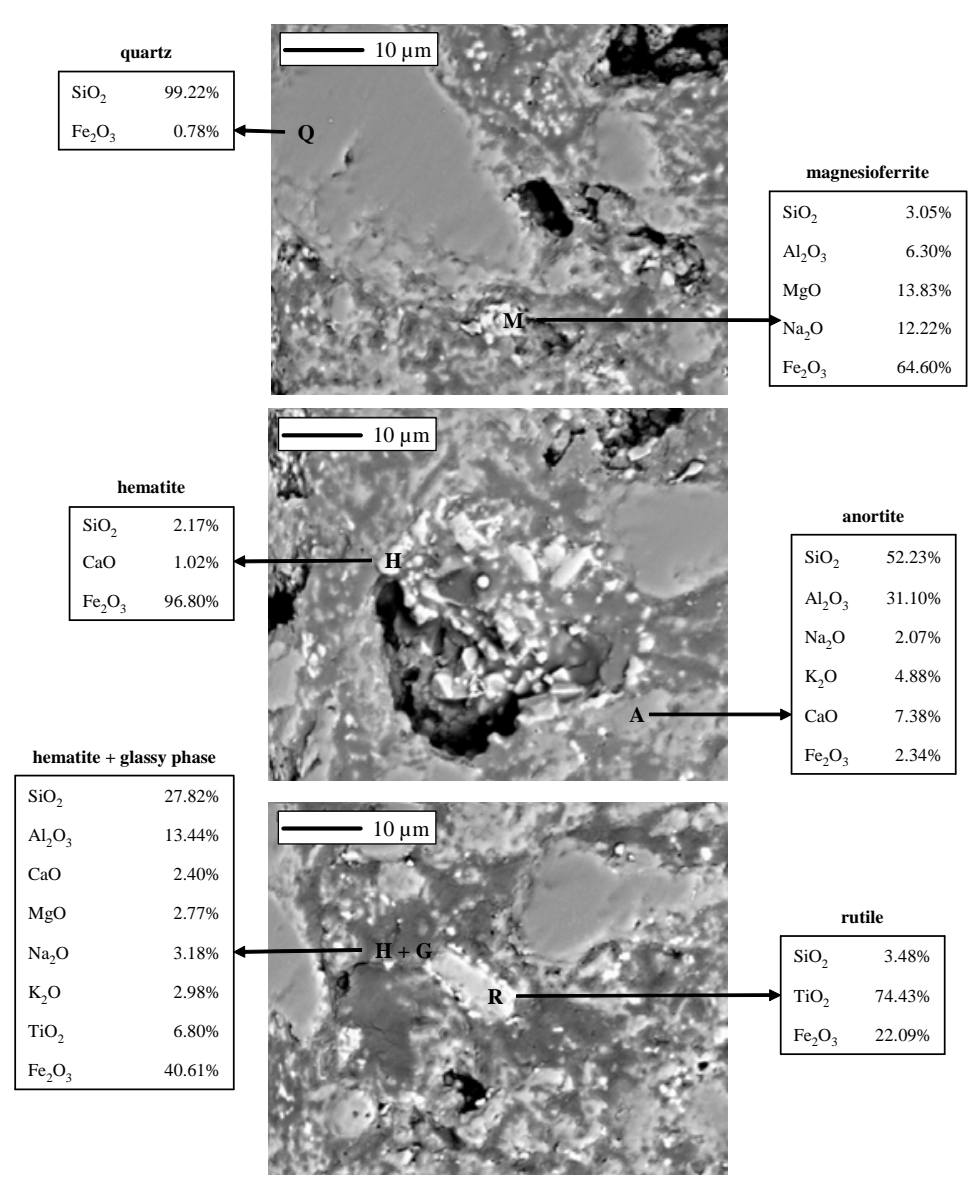

Figure 10. EDS analyses collected on different crystals in Cuchia sediment sintered at $1125^{\circ} \mathrm{C} / 1$ hour.

\section{Conclusion}

Ceramic bodies from three contaminated marine sediments have been fully characterised in terms of both phase evolution during firing and microstructure at the optimum sintering temperature.

The mineralogical evolution examined by X-ray diffraction (XRD) revealed that quartz, which is a main crystalline phase in the original marine sediments, remains as a main phase in the sintered bodies. In addition, a new crystalline phases, such as hematite $\left(\mathrm{Fe}_{2} \mathrm{O}_{3}\right)$, augite $\left(\mathrm{Ca}(\mathrm{Mg}, \mathrm{Fe}) \mathrm{Si}_{2} \mathrm{O}_{6}\right)$, magnesioferrite $\left(\mathrm{MgO} \cdot \mathrm{Fe}_{2} \mathrm{O}_{3}\right)$, ferrosilite $\left((\mathrm{Mg}, \mathrm{Fe}) \mathrm{Si}_{2} \mathrm{O}_{6}\right)$ and magnesium iron aluminium silicate $\left((\mathrm{Mg}, \mathrm{Fe}, \mathrm{Al})(\mathrm{Si}, \mathrm{Al}) \mathrm{O}_{3}\right)$ appear as result of different chemical reactions during firing. Besides, a glassy phase is formed as result of the dissolution of quartz grains and augite decomposition. In most cases, the increasing of sintering temperature gives rise to a partial dissolution of quartz and therefore, the amount of amorphous phase increases. 
M. Romero, A. Andrés, R. Alonso, J. Viguri, J.Ma. Rincón, Phase evolution and microstructural characterization of sintered ceramic bodies from contaminated marine sediments, Journal of the European Ceramic Society, 29 (2009) 15-22; doi:10.1016/j.jeurceramsoc.2008.04.038

Scanning electron microscopy (SEM) showed a homogeneous microstructure composed by isolated rounded pores, irregular shape and size crystals and a ceramic matrix surrounding the former phases. Energy dispersive spectroscopy (EDS) analyses permitted to distinguish the crystalline phases previously identified by XRD and also minor phases containing titanium, such as rutile $\left(\mathrm{TiO}_{2}\right)$ and $\mathrm{MgTiO}_{3}$, which were not detected in the X-ray diffractograms. EDS analyses also allowed detecting the incorporation of $\mathrm{Fe}^{3+}$ ions into the crystalline network of rutile.
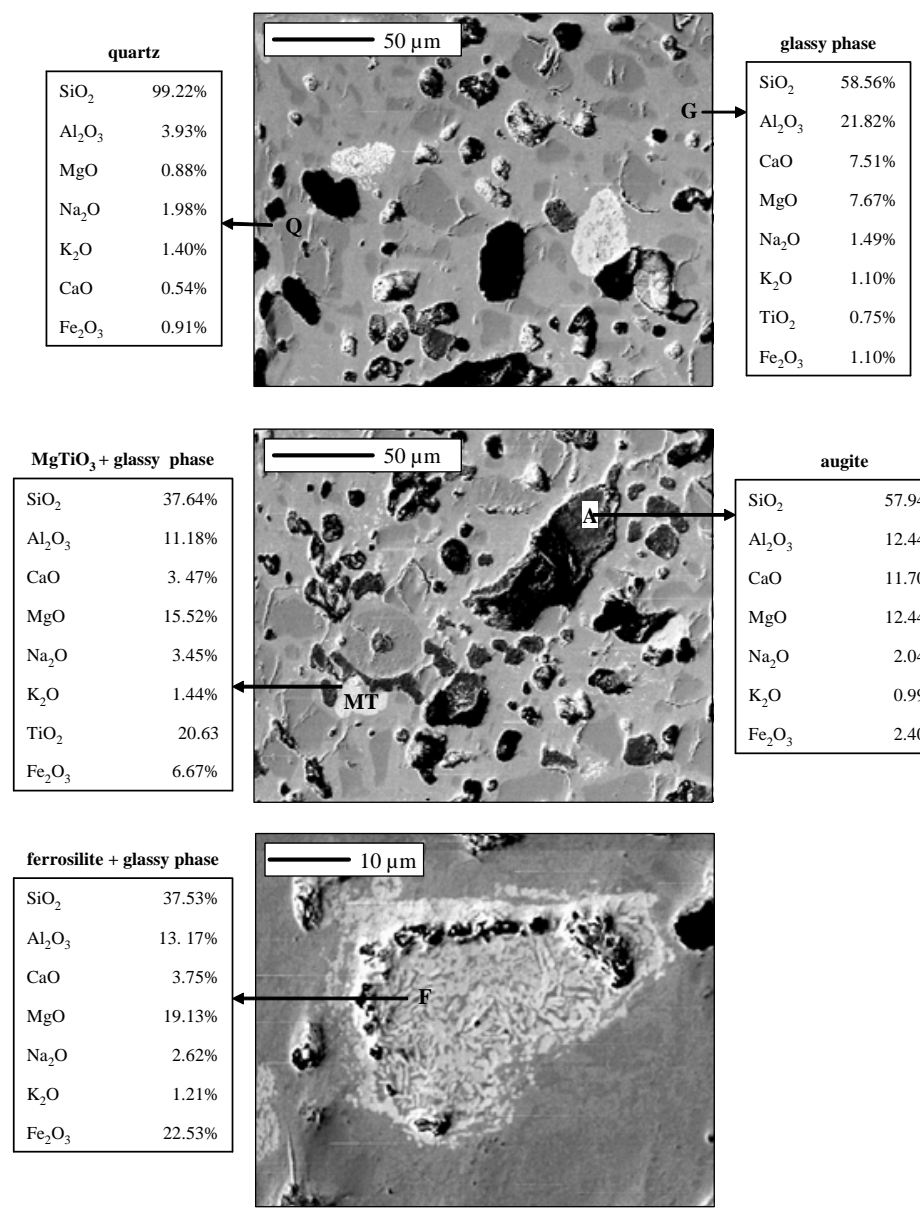

Figure 11. EDS analyses collected on different crystals in Raos sediment sintered at $1150^{\circ} \mathrm{C} / 1$ hour.

\section{Acknowledgements}

This research was supported by the Spanish Education and Science Ministry (Projects CTM 2005-07282-C03/03 and CTM 2006-07960). The authors thank to C. Rivera from University of Castilla-La Mancha (Spain) for his experimental assistance in X-ray diffraction. 
M. Romero, A. Andrés, R. Alonso, J. Viguri, J.Ma. Rincón, Phase evolution and microstructural characterization of sintered ceramic bodies from contaminated marine sediments, Journal of the European Ceramic Society, 29 (2009) 15-22; doi:10.1016/j.jeurceramsoc.2008.04.038

\section{References}

1. Chapman, P. M. \& Anderson, J., A decision-making framework for sediment contamination. Intgr. Environ. Asses. Manag., 2005, 3, 163-173.

2. PIANC 2006. Generic Biological Assess Guidelines For Dredged Material. Port International Association for Navigation and Commerce. Technical report workgroup EnviCom 8.

3. OSPAR Commission 2004. Revised OSPAR Guidelines for the Management of Dredged Material. Reference number: 2004-08.

4. DelValls, T. A., Andrés, A., Belzunce, M. J., Buceta, J. L., Casado-Martínez, M. C., Castro, R., Rib, I., Viguri, J. R. \& Blasco, J., Chemical and ecotoxicological guidelines for managing disposal of dredged material. Trac-Trends Anal. Chem., 2004, 23, 819-828.

5. Viguri, J., Verde, J. \& Irabien, A., Environmental assessments of polycyclic aromatic hydrocarbons (PAHs) in the surface sediments of the Santander Bay, Northern Spain. Chemosfere, 2002, 48, 157-165.

6. Rodriguez, P., Arrate, J., Martínez-Madrid, M., Schumacher, V., Reynoldson, T. B. \& Viguri, J., Toxicity of Santander Bay sediments to the eurihaline freshwater oligochaete Limnodrilus hoffmeisteri. Hydrobiologia, 2006, 564, 157-169.

7. Gonzalez-Piñuela, C., Coz, A., Andres, A., Irabien, M.J., Justa, I. \& Viguri JR., PAHs composition in surface and core sediments from the Santander Bay (Northern Spain). Fresen. Environ. Bull., 2006, 15, 1031-1036.

8. González-Antolin, M., González-Piñuela, C., Coz, A., Andres, A. \& Viguri, J. R., Extractable organic halogens (EOX) in estuarine sediments of Cantabria, Nothern Spain. In Proceedings of $3^{\text {rd }}$ Conference of the SedNet Work Package 3: Quality and impact assessment, Lisbon, 2004, p. 90.

9. Dondi, M., Marsigli, M. \& Fabbri, B., Recycling of industrial and urban wastes in brick production — a review. Tile Brick Int., 1997, 13, 218-225.

10. Fernandez Gómez, N., Rivero Gutierrez, S., Viguri, J. R. \& Andres, A., Reusing of waste materials in ceramic: analysis of scientific-technical information. In $10^{\text {th }}$ Mediterranean Congress on Chemical Engineering, Barcelona, 2005.

11. Caligaris, R., Quaranta, N., Caligaris, M. \& Benavidez, E., Materias primas no tradicionales en la industria ceramica. Bol. Soc. Esp. Ceram. Vidr., 2000, 39, 623626.

12. Demir, I., An investigation on the production of construction brick with processed waste tea. Build. Environ., 2006, 41, 1274-1278.

13. Demir, I., Baspinar, M. S. \& Orhan, M., Utilization of kraft pulp production residues in clay brick production, Build. Environ., 2006, 40, 1533-1537.

14. Cernec, F., Zule, J., Moze, A. \& Ivanus, A., Chemical and microbiological stability of waste sludge from paper industry intended for brick production, Waste Manag. Res., 2005, 23, 106-112.

15. Lin, K.L., Chiang, K.Y. \& Lin, D.F., Effect of heating temperature on the sintering characteristics of sewage sludge ash, J. Hazard. Mater., 2006, 128, 175181. 
M. Romero, A. Andrés, R. Alonso, J. Viguri, J.Ma. Rincón, Phase evolution and microstructural characterization of sintered ceramic bodies from contaminated marine sediments, Journal of the European Ceramic Society, 29 (2009) 15-22; doi:10.1016/j.jeurceramsoc.2008.04.038

16. Anderson, M. \& Skerratt, R.G., The inclusion of alum-based waterworks sludge (WTR) in commercial clay building bricks. Tile Brick Int., 2003, 19, 328-335.

17. Acchar, W., Vieira, F.A. \& Hotza, D., Effect of marble and granite sludge in clay materials, Mat. Sci. Eng., 2006, 419, 306-309.

18. Lin, K.L., Feasibility study of using brick made from municipal solid waste incinerator fly ash slag. J. Hazard. Mater., 2006, 137, 1810-1816.

19. Vieira, C. M. F., Andrade, P. M., Maciel, G. S., Vernilli Jr, F. \& Monteiro, S. N., Incorporation of fine steel sludge waste into red ceramic. Mat. Sci. Eng., 2006, 427, 142-147.

20. T. Kavas, Use of boron waste as a fluxing agent in production of red mud brick. Build. Environ., 2006, 41, 1179-1783.

21. Aineto, M., Acosta, A. \& Iglesias, I., The role of a coal gasification fly ash clay additive in building ceramic. J. Eur. Ceram. Soc., 2006, 26, 3783-3787

22. Monteiro, S. N., Alexandre, J., Margem, J. I., Sánchez, R. \& Vieira, C. M. F., Incorporation of sludge waste from water treatment plant into red ceramic. Con. Build. Mat., in press, doi:10.1016/j.conbuildmat.2007.01.013.

23. Romero, M., Andrés, A., Alonso, R., Viguri, J. \& Rincón, J.Ma., Sintering behaviour of ceramic bodies from contaminated marine sediments. Ceram. Int., doi:10.1016/j.ceramint.2007.07.002.

24. Burton, B. P. \& Lindsley, D. H., The interplay of chemical and magnetic ordering. Oxide minerals; petrologic and magnetic significance. Rev. Mineral., 1991, 25, 303-322.

25. Fujii T., Kayano M. \& Takada Y., Ilmenite-hematite solid solution films for novel electronic devices. Solid State Ionics, 2004, 172, 289-292. 